\title{
India goes to sea for research funds
}

New Delhi. Indian scientists want to turn the blood of the horseshoe crab Limulus polyphemus into a lucrative business whose profits can support all areas of science in the country. But US companies already working in the field say that the Indians have greatly overestimated the world market for the product, and they predict that such a windfall is highly unlikely.

The blood of the horseshoe crab is the source of amoebocyte lysate (AL), a chemical that can be used to test for bacterial toxins. It is used by pharmaceutical companies to demonstrate the safety of their injectable drugs and of medical devices that come into direct contact with the bloodstream, such as heart valves or balloon catheters. The test is more sensitive than the previous method, which involved rabbits, and takes only three hours instead of three or four days.

The marine creatures can be bled and returned unharmed to their habitat. A single crab can supply $20 \mathrm{ml}$ of blood that can yield $5 \mathrm{ml}$ of AL. That amount of reagent sells for US $\$ 25$ or more, depending on how it is formulated and packaged.

The National Institute of Oceanography (NIO) has set up a facility in Orissa, along
India's eastern coast, to extract AL. It is asking the government for money to scale up the operation to a commercial size. The supply appears bountiful: unlike its American cousin which breeds during the late spring and summer, the Indian crab breeds all year round. The horseshoe crab is also found along the northern shores of Japan and on the southern tip of China.

NIO scientists believe that there is no limit to the amount of crab blood that India can supply to the world's pharmaceutical industry. They talk of a market of US $\$ 5,000$ million, and profits that could finance the country's entire research budget.

That view is "wildly optimistic", says Michael Dawson, assistant director of Associates of Cape Cod, Massachusetts, the world's largest producer of the reagent. Although Dawson would not disclose the annual sales of the privately held company, he says that he doubts very much if the world market is 1 per cent of the amount being discussed in India.

"I think that the market is much more mature than they would like to believe", he says. Although demand for the product has risen steadily since the company was founded in 1974 by Stanley Watson of the

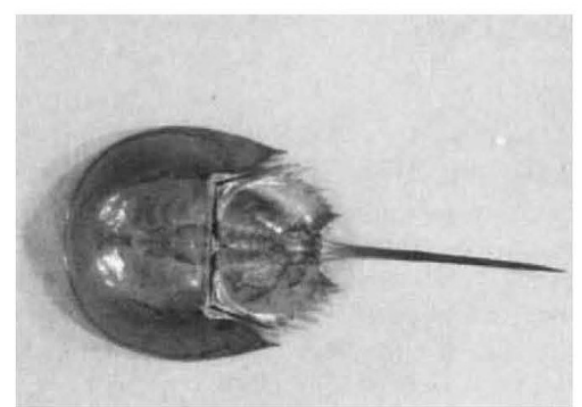

Horseshoe crab's blood seen as source of revenue for research by Indian scientists, but US producers question size of market.

Woods Hole Oceanographic Institution, Dawson says that the limiting factor is demand, not production capacity or the supply of crabs. "If people wanted to buy 10 times as much reagent, we could sell it to them", he says.

But Indian scientists are not deterred by such sombre forecasts. They believe that the market for their product, especially in the developing world, is growing rapidly. And they hope to persuade the government that theirs is a gamble well worth taking.

K.S. Jayaraman

\section{Marine blasts to be regulated following UK protest}

London. Procedures for setting off marine explosions in the name of research are likely to change following recent protests by the environmental group Greenpeace over work being carried out by the British Geological Survey (BGS). Although Greenpeace's objections did not stop a detonation off the coast of Wales - bad weather had already caused it to be postponed - the ensuing publicity drew attention to the fact that there are no formal procedures for regulating such work.

The BGS's marine blast was planned for Cardigan Bay over the weekend of 9-10 May. It marked the final stage in a study of the deep basement structure $6-8 \mathrm{~km}$ below the surface of Wales. A series of land detonations had already been set off without complaint.

Although the Geological Survey insists that its informal procedures for assessing the environmental impact of marine explosions are more than adequate, it says that subsequent studies will require a written protocol, including an assessment of possible effects on marine wildlife. Greenpeace was particularly concerned that the blast could harm bottlenose dolphins and harbour porpoises.

Although BGS will probably implement new procedures, the Department of the En- vironment has no plans for legislation on the matter. One reason is that a legislative solution would probably have to cover marine explosions carried out by the military as well as those by researchers. Much less is known about military detonations, but both the geologists and Greenpeace agree that these are much larger than those used in geological work.

In response to Greenpeace's protest, BGS prepared a detailed written protocol for the blast. Although BGS believes that the protocol differs little from the conclusions reached by its informal methods, additions include a diver to ensure that the charge is properly in place and a limit of 25 $\mathrm{kg}$ of explosives. The original plan called for a charge of as much as $50 \mathrm{~kg}$ if sea conditions were rough to make sure that the vibrations would not be dissipated.

The marine blast was finally postponed earlier this week when the group responsible for monitoring sea mammals in the area - the Dyfed Wildlife Trust - withdrew from the project. BGS was unwilling to go ahead with the detonation without suitable monitoring, and is blaming pressure from Greenpeace for the group's withdrawal. The blast will go ahead at a later date, but reassembling the monitoring equipment will cost several thousand pounds.
Greenpeace has said that if it is unhappy with the situation in the future it will intervene again.

Although geologists say that the written protocols are no great burden, they worry that whatever measures are taken will not satisfy groups such as Greenpeace. At the same time, marine biologists welcome the increased scrutiny being given to such detonations.

"It is quite unacceptable that people go about letting off charges without following some sort of guidelines," said Christine Lockyer of the Natural Environment Research Council's Sea Mammal Research Unit. Although researchers from the unit were consulted as part of BGS's informal assessment, they were not entirely happy with the situation. "We were given no details of how the charge was to be set off or how much explosive would be used", said Lockyer.

In the past, protests by Greenpeace that detonations used in oil exploration were killing fish led oil companies working in the North Sea to abandon explosives in favour of air-gun arrays. Geologists have also adopted air guns, which are supposedly less damaging, but the guns are not sufficiently powerful for deep structure studies.

lan Mundell 